\title{
A CROSS-CONTINENTAL EXAMINATION AND COMPARISON OF DESCRIPTIVE CRITERIA IN MARKETING JOURNALS - AMJ, EJM AND JM
}

\author{
Göran Svensson ${ }^{1}$ \\ Greg Wood 2
}

\begin{abstract}
The objective is to perform a cross-continental examination and comparison of non-traditional descriptive criteria in a selection of leading academic journals in marketing. The sample of journals is restricted to the examination and comparison of three academic journals in marketing. The journal sample consists of the Australasian Marketing Journal (AMJ), the European Journal of Marketing (EJM) and the Journal of Marketing (JM). Empirical research manuscripts dominate in the selected marketing journals. In addition, in the selected journals regular issues dominate in favour of special issues. The descriptive criteria examined and compared in AMJ, EJM and JM are based upon the content analysis of 811 manuscripts published during a six-year period, namely 2000-2005. Manuscripts of types other than empirical research, such as general reviews, literature reviews, conceptual papers, commentaries and book reviews are less likely to get published. Special issues or special sections are less frequent in these journals. This may lead to the situation that specialized journals in sub-areas of marketing may provide better and more comprehensive leading edge coverage and knowledge. The insights provided are in particular valuable for those scholars that do not usually get involved in academic publishing and consequently have a limited understanding and experience of the publication arena of manuscripts in leading academic journals. These insights also will be informative for more experienced academic publishers as they highlight certain characteristics of these journals that enlighten one as to the journals that one should target for publication and the difficulty, just on a numbers basis alone, of getting published in one of these three journals. The principal contribution of this research is the examination and comparison of descriptive criteria in AMJ, EJM and JM - a cross-continental sample of journals and criteria that have not been explored or reported previously in literature.
\end{abstract}

Key words: Marketing. Journals. Descriptive. Criteria. Examination. Comparison. Cross-continental.

\section{INTRODUCTION}

The examination and comparison of different academic journals has been going on for more than three decades in economics (e.g. Hawkins, Ritter and Walter, 1973; Danielsen and Delorme, 1976). In management and marketing, it has been a topic of interest for a couple of decades (e.g. Stahl, Leap and Wei, 1988; Jobber and Simpson, 1988; Luke and Doke, 1987; Fry, Walters and Scheuermann, 1985). Basically, two descriptive criteria have been used to examine and compare academic journals (e.g. Mason, Steagall, and Fabritius, 1997; Kim, 1991). One criterion to describe marketing journals is based upon citations (e.g. Baumgartner and Pieters, 2003; Jobber and Simpson, 1988), while the other is based upon perceptions (e.g. Brown and Becker, 1991; Luke and Doke, 1987). Polonsky, Jones and Kearsley (1999) provide another descriptive criterion of marketing journals based upon accessibility. Czinkota (2000), Rosenstreich and Wooliscroft (2005) and Svensson (2005) examine

\footnotetext{
1 Oslo School of Management Norway, Oslo, Noruega. E-mail: goran.svensson@hh.se.

2 Deakin University, Australia. E-mail: gwood@ deakin.edu.au.
} 
and compare the author affiliations in key academic marketing journals. In addition, Emerald (Emerald Management Reviews, 2004) used a set of descriptive criteria. It was based upon four criteria. The examination and comparison of these descriptive criteria produced four separate journal lists. Furthermore, Day and Peters (1994) use different descriptive criteria based upon journal publishing. Polonsky and Whitelaw (2005) raise the question of what is evaluated in the ranking of journals.

Consequently, different descriptive criteria have been used to examine and compare marketing journals in literature. These criteria are mostly used to rank journals in relation to each other (e.g. Hawes and Keillor, 2002). Is the relative rank the only area of interest to describe academic marketing journals? The authors contend that it is not. Cross-continental examinations of marketing journals are rarely performed (e.g. Theoharakis and Hirst, 2002). In this paper, we focus on a set of core descriptive criteria of which all journals consist, such as the content of editorial descriptions, the number and type of manuscripts published, volume- and issue-related criteria. The use of non-traditional criteria will generate a different examination and comparison to the previous ones reported in the literature. Consciously, we omit the subjective nature of perceived quality and the relative ranking of journals. On the contrary, our research is based upon the examination and comparison of each journal's volume and issues. Consequently, we believe that the examination and comparison of academic marketing journals is not only a matter that should be based upon estimated quality or ranking, but that they should also be examined and compared based upon other descriptive criteria.

Academic marketing journals represent a forum for marketing scholars in the research community to communicate their research efforts and thoughts. It would appear to us that most research published in academic marketing journals seems to be mainly restricted to researchers in North America and Western Europe and to a minor extent to researchers in Australia and Asia, therefore, an initial awareness and knowledge of the content in editorial descriptions of journals would be fruitful. It also would be useful to broaden the understanding of academic journals in terms of the number and type of published manuscripts, and the volume- and issue-related criteria. These findings would provide valuable insights for authors to target the appropriate journal for their manuscripts and to understand the enormity of the task of getting published. For example, the outcome of these descriptive criteria between journals - and journals across continents - may vary. Our objective is to perform a cross-continental examination and comparison of non-traditional descriptive criteria in a selection of leading academic journals in marketing.

\section{FRAME OF REFERENCE}

There have been many different approaches undertaken to explore the field of academic journals. One of them is the compilation of aggregated lists. For example, Harzing (2000-2006) compiles a list that is updated periodically. The current list contains 16 different rankings of 861 journals. It is a collation of journal rankings from a variety of sources and they are reported separately. Consequently, it is based upon a large number of cross-disciplinary journals, all of which also include marketing journals. On the contrary to Harzing (2000-2006), Emerald (Emerald Management Reviews, 2004) applied several criteria that underpinned the compilation of four differentiated journal lists. These lists provided cross-disciplinary rankings of journals, including marketing journals and they were continuously updated by Emerald.

The examination and comparison of a research discipline's journals may be derived from many different criteria (e.g. Beed and Beed, 1996; Hawes and Keillor, 2002; Jones, Brinn and Pendlebury, 1996; Parnell, 1997; Rice and Stankus, 1983; Zinkhan and Leigh, 1999). For example, Parnell (1997) provides a taxonomy of journal quality based upon expert opinion surveys, citation counts, or a combination of both. Rice and Stankus (1983) provide criteria of journal quality such as: citation analysis 
of the journal (e.g. Social Sciences Citation Index), acceptance rate of the journal (e.g. Cabell's Directory), sponsorship of the journal (e.g. American Marketing Association), fundament of the journal (e.g. authors, editor, review board, and their affiliation), and objective of the journal (e.g. methodological approaches and readership). Hawes and Keillor (2002) write that higher status is usually attributed to journals that publish articles that are theoretical, scholar-oriented, highly quantitative or technical in nature.

There are numerous lists based upon perceptions of journal quality (e.g. Mylonopoulos and Theoharakis, 2001; Van Fleet, McWilliams and Siegel, 2000; DuBois, 2000; Trieschmann, Dennis and Northcraft and Niemi, 2000; Nisonger, 1999; Hult, Neese and Bashaw, 1997; and Enomoto, 1993). Informal lists are also used in business schools (Brumbaugh, 2002). The access to formal lists appears to be important when research should be evaluated (e.g. Theoharakis and Hirst, 2002; Van Fleet, 2000; Hult, Neese and Bashaw, 1997).

In the literature, there has been an ongoing interest and discussion of the ranking of marketing journals. (e.g. Mort, McColl-Kennedy, Kiel and Soutar, 2004; Theoharakis and Hirst, 2002; Polonsky, Jones and Kearsley, 1999; Hult, Neese and Bashaw, 1997). Historically, most research efforts to rank marketing journals have been based upon scholars in North America (e.g. Fry et al., 1985; Luke and Doke, 1987; Hult, Neese and Bashaw, 1997). Recently, a few other research efforts have been done in the Asia Pacific Region (e.g. Mort, McColl-Kennedy, Kiel and Soutar, 2004; Polonsky, Jones and Kearsley, 1999; Polonsky and Waller, 1993). Theoharakis and Hirst (2002) performed a worldwide survey. In addition, Easton and Easton (2003) focused on the UK. We believe that the perceived quality and the relative ranking of journals are not the only criteria of interest, but other measures would enhance the ongoing examination and comparison of academic marketing journals.

The number of marketing journals has increased continuously during the last decades (Baumgartner and Pieters, 2003). Cabell (1997-98) has listed more than 550 marketing journals. Marketing journals have become more specialised (Baumgartner and Pieters, 2003; Malhotra, 1999). There is also a need among scholars to publish their research (e.g. Moxley, 1992). Mort, McCollKennedy, Kiel and Soutar (2004) acknowledge that today publishing in journals is a standard way through which academics communicate their research. Peer reviewed journals are the target for this dissemination. In consequence, a series of books has been published to facilitate and to provide guidelines on how one publishes in journals (e.g. Lester and Lester, 2005; Booth, Colomb and Williams, 2003; Rozakis, 1999; Day, 1996). In addition, Day and Peters (1994) explore the quality indicators in academic publishing.

There have been numerous examinations and comparisons of journals (Hawes and Keiller, 2002). A few principal descriptive criteria are used. One criterion is based upon citation analyses (e.g. Baumgartner and Pieters, 2003; Jobber and Simpson, 1988). The citation index is often interpreted to be unbiased and a true description of journals, however, journals from some regions may be missing (e.g. Nobes, 1995). Day and Peters (1994) argue that the citation index is dangerously flawed in that it is heavily biased towards high circulation journals, suffers from a single-item syndrome and that there is no direct correlation with quality per se. In addition, databases tend be restricted to a selection of journals (e.g. Neway and Lancaster, 1983), which may exclude a variety of other journals (e.g. journals published in other languages than English tend to be excluded, such as French, German, Spanish and/or other languages).

Another criterion is based upon perceptual evaluations of journals (e.g. Brown and Becker, 1991; Luke and Doke, 1987). The perceptually based descriptions may vary and be biased for different reasons. These descriptions may be influenced by institutional and individual demographics (e.g. Hult, Neese and Bashaw, 1997). For example, research has focused on leading institutions (e.g. Theoharakis and Hirst, 2002), active researchers/Deans/Heads of Schools (e.g. Mort, McColl-Kennedy, Kiel and Soutar, 2004; Brown and Becker, 1991). The objective or focus of the description may have an impact 
too (e.g. Polonsky and Waller, 1993), as well as regional variations (e.g. Danielsen and Delorme, 1976; Theoharakis and Hirst, 2002) and the journal's focus (e.g. Danielsen and Delorme, 1976; Hawkins, Ritter and Walter, 1973). The outcomes of studies of marketing journals vary due to the descriptive criteria (i.e. very often a single-item measure) that are applied (Hawes and Keiller, 2002; Polonsky, Jones and Kearsley, 1999; Polonsky and Waller, 1993).

\section{METHODOLOGY}

The sample that we have used is restricted to the examination and comparison of three academic journals in marketing during a six-year period. They have been selected to represent the academic marketing communities in North America, Europe and Australia (Asia). The journal sample consists of the Australasian Marketing Journal (AMJ), the European Journal of Marketing (EJM) and the Journal of Marketing (JM). The examination and comparison of these journals is limited to the following descriptive criteria:

- the editorial descriptions,

- the number of manuscripts published,

- the issue of publication,

- the year of publication (i.e. volume),

- the number of regular issues,

- the number of special issues, and

- the type of manuscripts published.

Qualitative data was collected to explore the editorial descriptions of the selected marketing journals. The data was retrieved from the official homepage on the internet of each journal. An initial browsing of the sample was performed to get insights and based upon this procedure the time frame of the examination and comparison of descriptive criteria was limited to the beginning of 2000 to the end of 2005. Each volume, issue and manuscript in the selected journals was examined and classified into different categories according to the descriptive criteria. The data was quantified and the descriptive criteria have been used in cross-tabulations (except for the editorial descriptions) to facilitate comparisons between journals and their continental belonging. All manuscripts published in these three journals during the period 2000-2005 were examined. In total, the content analysis consisted of 811 manuscripts in the selected sample of academic marketing journals.

\section{DESCRIPTIVE CRITERIA OF AMJ, EJM AND JM}

The descriptive criteria examined and compared in this section are based upon the content analysis of 811 manuscripts published 2000-2005 in AMJ, EJM and JM. The findings are summarised in Tables 1-9 
Table 1: Editorial Descriptions of AMJ, EJM and JM - 2000-2005.

\section{EDITORIAL DESCRIPTIONS}

\section{Australasian Marketing Journal (AMJ)}

AMJ is an academic journal written for both scholars and practitioners. The objective of the AMJ is to publish articles that enrich the practice of marketing while simultaneously contributing to the advancement of the discipline. Contributors are encouraged to focus on either conceptual or empirical work and to outline practical implications for marketing. Topics should always relate to some aspect of marketing. It is the intention to publish well-written, readable articles with broad appeal and of international relevance. AMJ is keen to publish more good papers which emanate from the Asia-Pacific region, or focus on the region in a global context.

\section{European Journal of Marketing (EJM)}

EJM provides a platform for contemporary ideas in marketing, the thinking, theory and practice. It aims to facilitate information among researchers on a worldwide basis and keep up to date with developments in European marketing and Europe in the global context. The journal contains leading edge marketing theory - supported by evidenced-based research, from the world's leading marketing thinkers. EJM provides a platform for new ideas in marketing. EJM offers unparalleled insights on new research, current practice and future trends so that practitioners and academics can gain a useful overview of marketing activity and apply that knowledge to develop appropriate strategies.

\section{Journal of Marketing (JM)}

JM's primary objectives are (1) to lead in the development, dissemination, and implementation of marketing concepts, practice, and information and (2) to probe and promote the use of marketing concepts by businesses, not-for-profits, and other institutions for the betterment of society. JM is positioned as the premier, broad-based, scholarly journal of the marketing discipline that focuses on substantive issues in marketing and marketing management. The journal is designed to bridge the gap between theory and application. The journal is widely circulated with a diverse readership that includes both practitioners and academics. By design, JM publishes articles on a variety of topics contributing to the advancement of the science and/or practice of marketing.

Sources: Australasian Marketing Journal (http://www.marketing.unsw.edu.au/ami); European Journal of Marketing (http://www.emeraldinsight.com/info/journals/ejm); and Journal of Marketing (http://www.marketingpower.com).

The selected academic journals (i.e. AMJ, EJM and JM) of marketing in Table 1 have a common denominator, in that they all aspire to be the leading academic marketing journal of their continental belonging. In particular, this applies to AMJ and EJM. JM aspires to be the leading journal in the world in marketing. Furthermore, AMJ, EJM and JM aim at a readership consisting of both scholars and practitioners. All of them also aspire to stimulate the discipline of marketing and the practice of marketing.

The editorial descriptions of the selected marketing journals indicate that they describe their published articles according to a few general criteria (see Table 1). One of these criteria is that they aim at being broadly oriented. For example, a variety of marketing topics are relevant for inclusion. Another criterion is that each of them also indicates (or wishes) that they too belong to the leading group of journals in their part of the world. Interestingly - despite the fact that they are primarily academic journals and apply a peer review processes - the readership is often intended to be both academics and practitioners. We wonder how many practitioners contemplate reading these academic marketing journals They also want to present new ideas and provide leading edge knowledge, which implicitly or explicitly is a part of their editorial objectives.

During the period 2000-2005, 811 manuscripts were published in AMJ, EJM and JM (see Table 2). EJM published 453 manuscripts. In this respect, it is by far the largest journal of the three selected. JM published approximately half of the amount of manuscripts to EJM, namely 244 . AMJ published only 
114 manuscripts in the same period. The latter may be due to the fact that it is a newer journal - that is, it has been (relatively speaking!) recently established. As a matter of fact, AMJ had volume 13 in 2005, while EJM and JM had volumes 39 and 69 respectively.

Table 2: Total Number of Manuscripts in AMJ, EJM and JM - 2000-2005.

\begin{tabular}{l|c|c}
\hline \multicolumn{1}{c|}{120} & MANUSCRIPTS & PERCENTAGE \\
\hline Australasian Marketing Journal & 114 & $14.1 \%$ \\
\hline European Journal of Marketing & 453 & $55.8 \%$ \\
\hline Journal of Marketing & 244 & $30.1 \%$ \\
\hline Total & $\mathbf{8 1 1}$ & $100.0 \%$ \\
\hline
\end{tabular}

In Table 3, it should be noted that there is an overall tendency for a larger number of manuscripts to be published in recent years than was the case in the past.

Table 3: Number of Manuscripts per Year of Publication (Volume) in AMJ, EJM and JM - 2000-2005.

\begin{tabular}{|c|c|c|c|c|c|c|c|}
\hline & \multicolumn{7}{|c|}{ MANUSCRIPTS PER YEAR OF PUBLICATION (VOLUME) } \\
\hline & 2000 & 2001 & 2002 & 2003 & 2004 & 2005 & \\
\hline $\begin{array}{l}\text { Australasian Marketing Journal } \\
\text { (Volumes 8-13) }\end{array}$ & 15 & 16 & 20 & 19 & 28 & $16^{*}$ & $\begin{array}{c}114 \\
(14.1 \%)\end{array}$ \\
\hline $\begin{array}{l}\text { European Journal of Marketing } \\
\text { (Volumes 34-39) }\end{array}$ & 72 & 71 & 76 & 78 & 82 & 74 & $\begin{array}{c}453 \\
(55.8 \%) \\
\end{array}$ \\
\hline $\begin{array}{l}\text { Journal of Marketing } \\
\text { (Volumes 64-69) }\end{array}$ & 35 & 30 & 34 & 34 & 49 & 62 & $\begin{array}{c}244 \\
(30.1 \%)\end{array}$ \\
\hline TOTAL & $\begin{array}{c}122 \\
(15.0 \%)\end{array}$ & $\begin{array}{c}117 \\
(14.4 \%)\end{array}$ & $\begin{array}{c}130 \\
(16.0 \%)\end{array}$ & $\begin{array}{c}131 \\
(16.2 \%)\end{array}$ & $\begin{array}{c}167 \\
(20.6 \%)\end{array}$ & $\begin{array}{c}144 \\
(17.8 \%)\end{array}$ & $\begin{array}{c}811 \\
(100 \%)\end{array}$ \\
\hline
\end{tabular}

In general, a larger number of manuscripts are squeezed into the same size format. For example, AMJ has gone from approximately 15-16 manuscripts per year to 20+ (i.e. an additional issue is published). EJM has increased from approximately 70 manuscripts per year to somewhere around 75-80 annually. Likewise, JM has moved from 30-35 manuscripts per year to approximately 50+ annually.

The reason may be that an increased number of manuscripts are submitted to these journals and that these submissions to a larger extent have adequate quality that succeeds in going through the review process of each journal. The interest in publishing in marketing journals may be indicative of a rise in the number of academics in the marketing field. Collectively they are pursuing more research and need an outlet in which to publish their efforts. As the quality output of publications is now more of a focus in some countries, these journals are being targeted by a growing band of academics in need of publishing kudos in such journals. A cynical possibility is that it may just be a numbers game to make one's journal appear bigger and better. 
Table 4: Number of Manuscripts per Issue and Year of Publication in AMJ, EJM and JM - 2000- 2005.

\begin{tabular}{|c|c|c|c|c|c|c|c|c|}
\hline \multirow{2}{*}{\multicolumn{2}{|c|}{ JOURNAL }} & \multicolumn{7}{|c|}{ MANUSCRIPTS PER ISSUE AND YEAR OF PUBLICATION } \\
\hline & & 2000 & 2001 & 2002 & 2003 & 2004 & 2005 & Total \\
\hline $\begin{array}{l}\text { Australasian Marketing } \\
\text { Journal } \\
\text { (Volumes 8-13) }\end{array}$ & 1) 2) & $\begin{array}{c}5 \\
10 \\
*\end{array}$ & $\begin{array}{l}8 \\
8 \\
\star\end{array}$ & $\begin{array}{l}6 \\
7 \\
7\end{array}$ & $\begin{array}{l}8 \\
5 \\
6\end{array}$ & $\begin{array}{c}10 \\
8 \\
10\end{array}$ & $\begin{array}{l}8 \\
8 \\
* \\
\end{array}$ & $\begin{array}{l}45 \\
46 \\
23\end{array}$ \\
\hline Subtotal (Mean Value) & & $15(7.5)$ & $16(8.0)$ & $20(6.7)$ & $19(6.3)$ & $28(9.3)$ & $16(8.0)$ & 114 \\
\hline $\begin{array}{l}\text { European Journal of } \\
\text { Marketing } \\
\text { (Volumes 34-39) }\end{array}$ & $\begin{array}{l}1 / 2) \\
3 / 4) \\
5 / 6) \\
7 / 8) \\
9 / 10) \\
11 / 12)\end{array}$ & $\begin{array}{l}14 \\
12 \\
12 \\
13 \\
11 \\
10\end{array}$ & $\begin{array}{c}13 \\
11 \\
13 \\
7 \\
14 \\
13\end{array}$ & $\begin{array}{l}13 \\
12 \\
12 \\
13 \\
12 \\
14\end{array}$ & $\begin{array}{c}15 \\
12 \\
9 \\
12 \\
17 \\
13\end{array}$ & $\begin{array}{c}14 \\
9 \\
15 \\
15 \\
15 \\
14\end{array}$ & $\begin{array}{c}13 \\
9 \\
15 \\
13 \\
15 \\
9\end{array}$ & $\begin{array}{l}82 \\
65 \\
76 \\
73 \\
84 \\
73\end{array}$ \\
\hline Subtotal (Mean Value) & & $72(6.0)$ & $71(5.9)$ & 76 6.3) & $78(6.5)$ & $82(6.8)$ & $74(6.2)$ & 453 \\
\hline $\begin{array}{l}\text { Journal of Marketing } \\
\text { (Volumes 64-69) }\end{array}$ & $\begin{array}{l}\text { 1) } \\
\text { 2) } \\
\text { 3) } \\
\text { 4) }\end{array}$ & $\begin{array}{c}12 \\
9 \\
7 \\
7\end{array}$ & $\begin{array}{l}7 \\
7 \\
8 \\
8\end{array}$ & $\begin{array}{c}8 \\
7 \\
9 \\
10\end{array}$ & $\begin{array}{c}8 \\
10 \\
9 \\
7\end{array}$ & $\begin{array}{c}17 \\
8 \\
10 \\
14\end{array}$ & $\begin{array}{c}9 \\
9 \\
12 \\
32\end{array}$ & $\begin{array}{l}61 \\
50 \\
55 \\
78\end{array}$ \\
\hline Subtotal (Mean Value) & & $35(8.7)$ & $30(7.5)$ & $34(8.5)$ & $34(8.5)$ & $\begin{array}{c}49 \\
(12.2)\end{array}$ & $\begin{array}{c}62 \\
(15.5)\end{array}$ & 244 \\
\hline TOTAL & & 122 & 117 & 130 & 131 & 159 & 152 & 811 \\
\hline
\end{tabular}

${ }^{*}$ No issue available.

Generally, JM includes more manuscripts per issue than AMJ and EJM. JM has in most cases almost 9 or more in each issue, while AMJ has mostly 7-8 and EJM has 6-7 manuscripts per issue. In addition, there is a slight trend that each issue of the selected journals (see Table 4) includes an increased number of manuscripts. In the last few years in particular, EJM and JM have a larger number of manuscripts in most issues. For example, EJM had mostly 10-13 per paired issues, but now it is more like 13-15 manuscripts. JM had mostly 7-8, but it has now 9-10 or even more manuscripts.

The increased number of manuscripts - is this a consequence of the increased need and pressure on academics in some parts of the world to publish their research efforts? If so, shorter and more straightforward manuscripts may provide additional space for manuscripts to be published thus accomplishing the quality requirements of each journal.

Table 5: Total Number of Regular and Special Issues in AMJ, EJM and JM - 2000-2005.

\begin{tabular}{l|c|c|c}
\hline \multicolumn{1}{c|}{ JOURNAL } & REGULAR ISSUE (\%) & SPECIAL ISSUE (\%) & TOTAL (\%) \\
\hline Australasian Marketing Journal & $12(70.6 \%)$ & $5(29.4 \%)$ & $17(15.0 \%)$ \\
\hline European Journal of Marketing & $48(66.7 \%)$ & $24(33.3 \%)$ & $72(63.7 \%)$ \\
\hline Journal of Marketing & $22(91.7 \%)$ & $2^{*}(8.3 \%)$ & $24(21.2 \%)$ \\
\hline Total & $82(72.6 \%)$ & $31(27.4 \%)$ & $113(100 \%)$ \\
\hline
\end{tabular}

* Labeled as "Special Section" and is part of a regular issue. 
Table 5 illustrates that regular issues dominate in the three selected journals. In fact, almost three quarters $(72.6 \%)$ of the issues are regular ones. JM hardly includes special issues (or special sections). AMJ and EJM dedicate approximately one third of their issues to special ones (29.4 and $33.3 \%$ respectively), while JM only has dedicated approximately $8 \%$ to special sections. In JM, $91.7 \%$ of issues are regular issues, while AMJ has $70.6 \%$ and EJM has $66.7 \%$ regular issues.

The phenomenon of special issues is interesting as it provides the opportunity for the broad marketing journals to publish more narrow-focused topics. Otherwise, the sub-disciplines of marketing would to a large extent be locked out from these broad coverage journals. We contend that it is highly appropriate to include special issues to gain the involvement and interest of different sub-disciplines into these journals. At the end of the day, they serve as a communicative interface between scholars within and between research societies.

Table 6: Number of Regular and Special Issues per Year of Publication (Volume) in AMJ, EJM and JM - 2000-2005.

\begin{tabular}{l|c|c|c|c|c|c|c}
\hline \multirow{2}{*}{ JOURNAL } & \multicolumn{7}{|c}{ YEAR OF PUBLICATION OF SPECIAL ISSUE (REGULAR ISSUE) } \\
\cline { 2 - 8 } & 2000 & 2001 & 2002 & $\mathbf{2 0 0 3}$ & $\mathbf{2 0 0 4}$ & $\mathbf{2 0 0 5}$ & Total \\
\hline $\begin{array}{l}\text { Australasian Marketing Journal } \\
\text { (Volumes 8-13) }\end{array}$ & 0 & 0 & 1 & 2 & 1 & 1 & 5 \\
$(16.1 \%)$ \\
\hline $\begin{array}{l}\text { European Journal of Marketing } \\
\text { (Volumes 34-39) }\end{array}$ & $4(8)$ & $2(10)$ & $6(6)$ & $5(7)$ & $3(9)$ & $4(8)$ & $\begin{array}{c}24 \\
(77.4 \%)\end{array}$ \\
\hline $\begin{array}{l}\text { Journal of Marketing } \\
\text { (Volumes 64-69) }\end{array}$ & $0(4)$ & $0(4)$ & $0(4)$ & $0(4)$ & $1^{*}(4)$ & $1^{*}(4)$ & $\begin{array}{c}2 \\
(6.5 \%)\end{array}$ \\
\hline Tota & $\begin{array}{c}4 \\
(12.9 \%)\end{array}$ & $\begin{array}{c}2 \\
(6.51 \%)\end{array}$ & $\begin{array}{c}7 \\
(22.6 \%)\end{array}$ & $\begin{array}{c}7 \\
(22.6 \%)\end{array}$ & $\begin{array}{c}4 \\
(12.9 \%)\end{array}$ & $\begin{array}{c}6 \\
(19.5 \%)\end{array}$ & $\begin{array}{c}31 \\
(100 \%)\end{array}$ \\
\hline
\end{tabular}

*Labeled as "Special Section" - part of a regular issue.

The inclusion of special issues in the three selected journals is a fairly recent phenomenon in AMJ and JM (see Table 6). EJM has included special issues continuously during the period examined. AMJ has for some time included special issues, while JM only until recently has had a couple of them. It should be noted that JM has not published any independent special issue, but the so-called special sections are part of a regular issue. Generally, one out of four regular issues in the journal sample is dedicated to a special issue.

Frequently, special issues are carried through and designed by the invitation of special issue guest editors who have a dedicated interest and expertise in the topic at hand. The use of guest editors also lightens the burden of the journal editor(s) - a task that per se usually requires a lot of time and dedication to serve the international academic society.

Table 7: Total Number of Type of Manuscript in AMJ, EJM and JM - 2000-2005.

\begin{tabular}{l|c|c}
\hline \multicolumn{1}{c|}{ TYPE OF MANUSCRIPT } & COUNT & PERCENTAGE \\
\hline Research & 531 & $65.5 \%$ \\
\hline Review* & 122 & $15.0 \%$ \\
\hline Book Review & 84 & $10.4 \%$ \\
\hline Commentary & 74 & $9.1 \%$ \\
\hline Total & 811 & $100.0 \%$ \\
\hline
\end{tabular}

* Includes general reviews, literature reviews, research proposals and conceptual papers. 
There are a variety of manuscripts published in AMJ, EJM and JM (Table 7). Four overall types of manuscripts may be distinguished: empirical research, theoretical research, commentaries and book reviews. Manuscripts based upon empirical research are to a large extent included in AMJ, EJM and JM. In fact, they represent almost two thirds (65.5\%). $15 \%$ is a compilation of general reviews, literature reviews or conceptual papers. Approximately one tenth $(9.1 \%)$ is based upon commentaries and another tenth (10.4\%) is based upon book reviews.

There appears to be a definite split between the different types of manuscripts. For example, a majority is based upon empirical research, but there is also room for theoretical and reflective ones, all of which may broaden and challenge current views and paradigms in marketing. It should be kept in mind that academia should be open-minded and provide ground-breaking research and proposals. A possible criticism may be to ask the question: Is the academic society open-minded and groundbreaking or is it not? Is there enough space for such ideas provided in academic outlets or have we become formulaic in our approaches?

Table 8: Type of Manuscripts in AMJ, EJM and JM - 2000-2005.

\begin{tabular}{l|c|c|c|c|c}
\hline \multicolumn{1}{c|}{ JOURNAL } & RESEARCH (\%) & $\begin{array}{c}\text { REVIEW* } \\
(\%)\end{array}$ & $\begin{array}{c}\text { COMMENTARY } \\
(\%)\end{array}$ & $\begin{array}{c}\text { BOOK REVIEW } \\
(\%)\end{array}$ & TOTAL \\
\hline Australasian Marketing Journal & 65 & $\begin{array}{c}9 \\
(57.0 \%)\end{array}$ & $\begin{array}{c}21 \\
(7.9 \%)\end{array}$ & $\begin{array}{c}19 \\
(18.4 \%)\end{array}$ & $\begin{array}{c}114 \\
(16.7 \%)\end{array}$ \\
\hline European Journal of Marketing & 294 & 97 & 24 & 38 & 453 \\
\hline Journal of Marketing & $(64.9 \%)$ & $(21.4 \%)$ & $(5.3 \%)$ & $(8.4 \%)$ & $(55.8 \%)$ \\
\hline Total & 172 & 16 & 29 & 27 & 244 \\
& $(70.5 \%)$ & $(6.5 \%)$ & $(11.9 \%)$ & $(11.1 \%)$ & $(30.1)$ \\
\hline
\end{tabular}

* Includes general reviews, literature reviews, research proposals and conceptual papers.

There are some differences between the types of manuscripts published in AMJ, EJM and JM (see Table 8). For example, JM has more than two thirds of the manuscripts based upon empirical research (70.5\%), while EJM has less than two thirds (64.9\%) and AMJ has a bit more than half of its manuscripts based upon empirical research (57.0\%). When it comes to reviews, EJM has more than one fifth (21.4\%) of its manuscripts in this category, while AMJ has only $7.9 \%$ and JM has $6.5 \%$. On the contrary, AMJ has almost one fifth of the manuscripts (18.4\%) dedicated to commentaries, where EJM has only $5.3 \%$. JM has $11.9 \%$ (that includes a series of eight brief commentaries on another manuscript in 2004). AMJ includes a larger share of book reviews (16.7\%) in relation to JM (11.1\%) and EJM (8.4\%).

The overwhelming number of manuscripts is based upon empirical research that in the marketing genre leans towards high-end quantitative analysis. Such analysis is usually not user friendly in respect to the non-academic practitioner and hence such a reliance on empirical work may disenfranchise the journals from a readership base of practitioners. The journals may be turned into academic-centric publications that may run the risk of losing touch with the wider world of the marketing discipline. 
Table 9: Type of Manuscript per Year of Publication in AMJ, EJM and JM - 2000-2005.

\begin{tabular}{|c|c|c|c|c|c|c|c|c|c|}
\hline \multirow{2}{*}{ JOURNAL } & \multirow{2}{*}{$\begin{array}{c}\text { TYPE OF } \\
\text { MANUSCRIPT }\end{array}$} & \multicolumn{8}{|c|}{ YEAR OF PUBLICATION } \\
\hline & & 2000 & 2001 & 2002 & 2003 & 2004 & 2005 & Mean & Total \\
\hline $\begin{array}{c}\text { Australasian Marketing } \\
\text { Journal } \\
\text { (Volumes 8-13) }\end{array}$ & $\begin{array}{c}\text { Research } \\
\text { Review* } \\
\text { Commentary } \\
\text { Book Review }\end{array}$ & $\begin{array}{l}10 \\
0 \\
5 \\
0\end{array}$ & $\begin{array}{l}8 \\
2 \\
6 \\
0\end{array}$ & $\begin{array}{l}11 \\
3 \\
4 \\
2\end{array}$ & $\begin{array}{c}14 \\
3 \\
2 \\
0\end{array}$ & $\begin{array}{c}12 \\
1 \\
4 \\
11\end{array}$ & $\begin{array}{c}10 \\
0 \\
0 \\
6\end{array}$ & $\begin{array}{c}10.8 \\
1.5 \\
3.5 \\
2.7\end{array}$ & $\begin{array}{c}65 \\
9 \\
21 \\
16\end{array}$ \\
\hline \multicolumn{2}{|c|}{ Subtotal } & 15 & 16 & 20 & 19 & 28 & 16 & & 114 \\
\hline $\begin{array}{l}\text { European Journal of } \\
\text { Marketing } \\
\text { (Volumes 34-39) }\end{array}$ & $\begin{array}{c}\text { Research } \\
\text { Review* } \\
\text { Commentary } \\
\text { Book Review }\end{array}$ & $\begin{array}{c}51 \\
11 \\
6 \\
4 \\
\end{array}$ & $\begin{array}{c}33 \\
29 \\
7 \\
2 \\
\end{array}$ & $\begin{array}{c}36 \\
28 \\
9 \\
3 \\
\end{array}$ & $\begin{array}{c}61 \\
10 \\
6 \\
1\end{array}$ & $\begin{array}{c}62 \\
10 \\
6 \\
4\end{array}$ & $\begin{array}{c}51 \\
9 \\
4 \\
10\end{array}$ & $\begin{array}{c}49.0 \\
16.1 \\
4.0 \\
6.3 \\
\end{array}$ & $\begin{array}{c}294 \\
97 \\
24 \\
38 \\
\end{array}$ \\
\hline \multicolumn{2}{|c|}{ Subtotal } & 72 & 71 & 76 & 78 & 82 & 74 & & 453 \\
\hline $\begin{array}{l}\text { Journal of Marketing } \\
\text { (Volumes 64-69) }\end{array}$ & $\begin{array}{c}\text { Research } \\
\text { Review* } \\
\text { Commentary } \\
\text { Book Review }\end{array}$ & $\begin{array}{c}22 \\
2 \\
3 \\
8\end{array}$ & $\begin{array}{l}24 \\
1 \\
0 \\
5\end{array}$ & $\begin{array}{c}25 \\
3 \\
1 \\
5\end{array}$ & $\begin{array}{c}29 \\
2 \\
0 \\
3\end{array}$ & $\begin{array}{c}32 \\
4 \\
10 \\
3\end{array}$ & $\begin{array}{c}40 \\
4 \\
15 \\
3\end{array}$ & $\begin{array}{c}28.7 \\
2.7 \\
4.8 \\
4.5\end{array}$ & $\begin{array}{c}172 \\
16 \\
29 \\
27\end{array}$ \\
\hline \multicolumn{2}{|c|}{ Subtotal } & 35 & 30 & 34 & 34 & 49 & 62 & & 244 \\
\hline \multicolumn{2}{|c|}{ Total } & 122 & 117 & 130 & 131 & 159 & 152 & & 811 \\
\hline
\end{tabular}

* Includes general reviews, literature reviews, research proposals and conceptual papers.

As a category, research manuscripts in AMJ (mean: 10.8 per year) and EJM (mean: 49.0 per year), has been fairly stable over the period examined, however, JM has recently increased the share of empirical research manuscripts (mean: 28.7 per year) that it publishes (Table 9). JM has increased the number of reviews (mean: 2.7 per year), while AMJ has dropped to almost none (mean: 1.5 per year). EJM had a peak for a couple of years with a triple amount of reviews, but is back now to a more modest amount (mean: 16.1 per year). Lately, commentaries have increased dramatically in JM (4.8 per year), while they have decreased slightly in AMJ (mean: 3.5 per year) and EJM (mean: 4.0 per year). Book reviews have increased substantially in AMJ (mean: 2.7 per year) and EJM (mean: 6.3 per year), but have decreased in JM (mean: 4.5 per year).

The outcome shows that there is a mix of manuscript types published in AMJ, EJM and JM. The question is: Is there a reasonable split between those that will stimulate the academic debate, evolution and progress of the marketing discipline? We may go back to older issues of marketing journals to find out what characterises manuscripts that became seminal works. Are they empirical, reviews or commentaries? We contend that the most valuable and insightful papers for both scholars and practitioners have not always been empirical, but rather published as reviews and commentaries, which have crossed borders and pushed the marketing discipline ahead. Many of these seminal works may not have been exhaustive in length. In fact, shorter may be better in this situation and perhaps one should encourage more pithy pieces than those that may ramble on to an obvious conclusion based on exhaustive empirical studies and analysis.

In fact, marketing phenomena are not always possible to test and verify empirically and statistically, because of the inaccessibility of appropriate data and the intangibility of the topic at hand. Approximates (e.g. multi-item measures and multivariate statistical techniques) are often used to underpin constructs and frameworks - sometimes neglecting common sense and the matters of course that govern the reality of marketing. Occasionally, practitioners raise their eye brows wondering - so 
what? Observation and intuition may provide interesting findings and in particular, those ideas based upon insightful experiences and wisdom from individuals that goes beyond time-specific and contextspecific concerns generally addressed in marketing research may be of real benefit. Intrinsic research values may stigmatise the marketing discipline if it does not recognise its inherent complexity. Human perception, human phenomena and human interactions are highly volatile and variable in and across marketing contexts over time, therefore, reviews and commentaries published in academic journals may contribute to the debate, the change and the advancement of the marketing discipline.

\section{CONCLUDING THOUGHTS}

In sum, there are some similarities between AMJ, EJM and JM as one might expect considering that they are all broad-oriented marketing journals. For example, they publish a broad range of topics however their continental belonging creates differences between them. Interestingly, the common denominator across the examined and compared descriptive criteria is limited to the types of manuscripts included in the issues of the journals, but not the relative distribution of them. There are major differences when it comes to the descriptive criteria of regular versus special issues, the number of issues per year, and the number of manuscripts per issue. In fact, there are also differences when it comes to the frequency of the type of manuscripts in the three examined journals.

The principal contribution of this research is the examination and comparison of descriptive criteria in AMJ, EJM and JM - a cross-continental sample that has not been explored previously. The insights provided contribute to the awareness and knowledge that empirical research manuscripts dominate in the selected marketing journals. In other words, other types of manuscripts are less likely to get published, such as general reviews, literature reviews, research proposals, conceptual papers, commentaries and book reviews. In addition, regular issues also dominate in the selected journals. Special issues or special sections are less frequent. Probably, this leads to the possibility that specialized journals in sub-areas of marketing - such as services marketing, industrial marketing, consumer behaviour or the other areas - may provide better leading edge coverage in their specific fields.

Finally, we believe that the insights provided are particularly valuable for not only those scholars that do not usually get involved in academic publishing and consequently have a restricted understanding or limited experience of the publication arena of manuscripts in leading academic journals, but also for the seasoned academic publisher as they enable one to see the current status of publishing across these leading continental journals.

In the six years of the study across the three journals, the aggregated number of manuscripts published was 811. Such an averaged figure of 45 papers per year per journal makes one realize that being published in one of these journals in one's own continent is not an easy task, in fact one could say that a publication in any one of them is an outstanding achievement. On the volume of publication grounds alone, it could be suggested that one has a better chance of publication in EJM and on a lack of competition grounds one may have a better chance of publication in AMJ, but what chance does one have of a publication in JM?

\section{REFERENCES}

Australasian Marketing Journal (2006), Retrieved from http://www.marketing.unsw. edu.au/amj, January 5. 
Baumgartner, H. and Pieters, R, (2003), "The Structural Influence of Marketing Journals: A Citation Analysis of the Discipline and its Subareas over Time", Journal of Marketing, Vol. 67, No. 2, pp. 123139.

Beed, C. and Beed, C. (1996), "Measuring the Quality of Academic Journals: The Case of Economics", Journal of Post Keynesian Economics, Vol. 18, No. 3, pp. 369-396.

Booth, W. C., Colomb, G. G. and Williams, J. M. (2003), The Craft of Research, Chicago Press.

Brumbaugh, A. (2002), "Response: Marketing Journal Rankings", ELMAR, July (www.elmar-list.org)

Cabell, D. W. E. (1997-98), Cabell's Directory of Publishing Opportunities in Management and Marketing, Cabell Publishing Co., Beaumont.

Czinkota, M. R. (2000), "International Information Cross-Fertilization in Marketing", European Journal of Marketing, Vol. 34, No. 11/12, pp. 1305-1314.

Danielsen, A. and Delorme, C. D. Jr. (1976), "Some Empirical Evidence on the Variables Associated with the Ranking of Economics Journals", Southern Economic Journal, Vol. 43, No. 2, pp. 1149-1160.

Day, A. (1996), How to Get Research Published in Journals, Gower House, Hampshire.

Day, A. and Peters, J. (1994), "Quality Indicators in Academic Publishing", Library Review, Vol. 43, No. 7, pp. 4-72.

DuBois, F. L. (2000), "Ranking the International Business Journals", Journal of International Business Studies, Vol. 31, No. 4, pp. 689-705.

Easton, G. and Easton, D. M. (2003), "Marketing Journals and the Research Assessment Exercise", Journal of Marketing Management, Vol. 19, No. 1/2, pp. 5-25.

Emerald Management Reviews, (2005), "Management Journal Rankings", retrieved from www.emeraldinsight.com, January 10. .

Enomoto, C. E. (1993), "A Stratified Approach to the Ranking of Economics Journals", Studies in Economic Analysis, Vol. 14, No. 2, pp. 74-94.

European Journal of Marketing (2006), Retrieved from http://www.emeraldinsight.com/ info/journals/ejm, January 5.

Fry, E. H., Walters, C. G. and Scheuermann, L. E. (1985), "Perceived Quality of Fifty Selected Journals: Academicians and Practitioners", Journal of the Academy of Marketing Science, Vol. 13, Spring, pp. 352-61.

Gordon, P. J. and Heischmidt, K. A. (1992), "Evaluation of Marketing Publications: Some New Findings", Enhancing Knowledge Development in Marketing, Vol. 3, pp. 318-319.

Harzing, A-W, (2000-2006), “Journal Quality List”, retrieved from www.harzing.com, January 7.

Hawes, J. M. and Keiller, B. (2002), "Assessing Marketing Journals: A Mission-Based Approach", Journal of the Academy of Business Education, Vol. 3, No. 2, pp. 70-86.

Hawkins, R. G., Ritter, L. S. and Walter, I. (1973), "What Economists Think of Their Journals", Journal of Political Economy, Vol. 81, No. 4, pp. 1017-1032. 
Hult, G. T. M., Neese, W. T. and Bashaw, R. E. (1997), "Faculty Perceptions of Marketing Journals", Journal of Marketing Education, Vol. 19, No. 1, pp. 37-52.

Jobber, D. and Simpson, P. (1988), "A Citation Analysis of Selected Marketing Journals", International Journal of Research in Marketing, Vol. 5, No. 2, pp. 137-142.

Jones, M. J., Brinn, T. and Pendlebury, M. (1994), “Journal Evaluation Methodologies: A Balanced Response", Omega: International Journal of Management Science, Vol. 24, No. 5, pp. 607-612.

Journal of Marketing (2006), American Marketing Association, Retrieved from http://www.marketingpower.com, January 5.

Kim, M. T. (1991), "Ranking Journals in Library and Information Science: A Comparison of Perceptual and Citation-Based Measures", College and Research Libraries, Vol. 52, No. 1, pp. 24-37.

Lester, D. J. and Lester, D. J. Jr. (2005), Writing Research Papers, Pearson Education.

Luke, R. H. and Doke, E. R. (1987), "Marketing Journal Hierarchies: Faculty Perceptions, 1986-1987", Journal of the Academy of Marketing Science, Vol. 15, No. 2, pp. 74-78.

Malhotra, N. K. (1999), "The Past, Present and Future of the Marketing Discipline", Journal of the Academy of Marketing Science, Vol. 27, No. 2, pp. 116-119.

Mason, P. M., Steagall, J. W. and Fabritius, M. M. (1997), "Economics Journal Rankings by the Type of School: Perceptions versus Citations", Quarterley Journal of Business \& Economics, Vol. 36, No. 1, pp. 60-79.

Mort, G. S., McColl-Kennedy, J. R., Kiel, G. and Soutar, G. N. (2004), "Perceptions of Marketing Journals by Senior Academics in Australia and New Zealand", Australasian Marketing Journal, Vol. 12, No. 2, pp. 51-61.

Moxley, J. M. (1992), Publish, Don't Perish: The Scholar's Guide to Academic Writing and Publishing, Greenwood Press, Westport.

Mylonopoulos, N. A. and Theoharakis, V. (2001), "Global Perceptions of IS Journals", Communications of the ACM, Vol. 44, No. 9, pp. 29-37.

Nisonger, T. E. (1999), "JASIS and Library and Information Science Journal Rankings: A Review and Analysis of the Last Half Century", Journal of the American Society for Information Science, Vol. 50, No. 11 , pp. 1004-1020.

Neway, J. M. and Lancaster, F. W. (1983), "The Correlation Between Pertinence and Rate of Circulation Duplication in Multidatabase Searches", Journal of the American Society for Information Science, Vol. 34, No. 4, pp. 292-293.

Nobes, C. W. (1985), "International Vacations in Perceptions of Accounting Journals", Accounting Review, Vol. 60, No. 4, pp. 702-705.

Parnell, J. A. (1997), "Assessing Management Journal Quality: A Methodological Critique and Empirical Analysis", The Mid-Atlantic Journal of Business, Vol. 33, March, pp. 69-83.

Polonsky, M. J. and Whitelaw, P. (2005), "What Are We Really Evaluating When We Rank Journals Comparisons of Views", Journal of Marketing Education, Vol. 27, No. 2, pp. 189-201 
Polonsky, M. J., Jones, G. and Kearsley, M. J. (1999), "Accessibility: An Alternative Method of Ranking Marketing Journals?", Journal of Marketing Education, Vol. 21, No. 3, pp. 181-193.

Polonsky, M. J. and Waller, D. S. (1993), "Marketing Journals and Asia-Pacific Marketing Academics", Asia-Australia Marketing Journal, Vol. 1, No. 1, pp. 61-69.

Rice, B. A and Stankus, T. (1983), "Publication Quality Indicators for Tenure or Promotion Decisions: What Can the Librarian Ethically Report?", College and Research Libraries, Vol. 44, March, pp. 173178.

Rosenstreich, D. and Wooliscroft, B. (2005) "What Does It Take to Get Published in a Top Marketing Journal from Australasia", 30th Annual Macromarketing Seminar, May 28-31, St. Petersburg, USA.

Rozakis, L. (1999), Schaum's Quick Guide to Writing Great Research Papers, McGraw-Hill.

Stahl, M. J., Leap, T. L. and Wei, Z. Z. (1988), "Publication in Leading Management Journals as a Measure of Insititutional Research Productivity", Academy of Management Journal, Vol. 31, No. 3, pp. 702-720.

Svensson, G. (2005), "Ethnocentricity in Top Marketing Journals", Marketing Intelligence \& Planning, Vol. 23, No. 5, pp. $422-434$.

Theoharakis, V. and Hirst, V. (2002), "Perceptual Differences of Marketing Journals: A Worldwide Perspective", Marketing Letters, Vol. 13, No. 4, pp. 389-402.

Trieschmann, J. S., Dennis, A. R., Northcraft, G. B. and Niemi, A. W. Jr. (2000), "Serving Multiple Constituencies in Business Schools: M.B.A. Program versus Research Performance", Academy of Management Journal, Vol. 43, No. 6, pp. 1130-1141.

Van Fleet, D. D., McWilliams, A. and Siegel, D. S. (2000), "A Theoretical and Empirical Analysis of Journal Rankings: the Case of Formal Lists", Journal of Management, Vol. 26, No. 5, pp. 839-861.

Zinkhan, G. M. and Leigh, T. W. (1999), "Assessing the Quality Ranking of the Journal of Advertising, 1986-1997", Journal of Advertising, Vol. 28, No. 2, pp. 51-70.

\section{UMA INVESTIGAÇÃO TRANSCONTINENTAL E UMA COMPARAÇÃO DOS CRITÉRIOS DESCRITIVOS EM PERIÓDICOS DE MARKETING- AMJ, EJM E JM.}

O objetivo é melhorar a investigação transcontinental e a comparação dos critérios descritivos não tradicionais numa seleção de periódicos acadêmicos de ponta na área de marketing. A amostragem de periódicos é restrita ao exame e comparação de três destes periódicos que são: Australian Marketing Journal (AMJ), European Journal of Marketing (EJM) e the Journal of Marketing (JM), nos quais predominam estudos de caráter empírico. Além disso, mostrou-se que, nos periódicos considerados, temas gerais predominam sobre edições especiais. 0 exame e comparação dos critérios estão baseados numa análise de contexto de 811 artigos publicados durante o período de seis anos, entre 2000-2005. Artigos que não são classificados dentro da categoria de estudos empíricos, tais como revisão geral, revisão da literatura, papers teóricos, revisão e comentários de livros são também menos publicados. Também, mostrou-se que, nestes periódicos, foram publicadas menos edições especiais ou seções especiais. A principal contribuição deste estudo reside na investigação e comparação dos critérios descritivos em periódicos de diferentes continentes, especialmente analisando critérios que não foram explorados e relatados previamente na literatura.

Palavras chave: Marketing. Periódicos. Descritivo. Critério. Investigação. Comparação. Transcontinental.

Data de Submissão: março de 2007 Data de Aceite: maio de 2007 